\title{
Rancang Bangun Sistem Kontrol Berbasis Biopotensial Mata (Studi Kasus : Mengontrol Aplikasi Berbasis Android)
}

\author{
Rahmat Maulana Yasin, Abdullah Nur Aziz*, Hartono \\ Fisika, FMIPA, Universitas Jenderal Soedirman \\ Corresponding Author:abd.nur.aziz@gmail.com
}

\begin{abstract}
Abstrak - Perbedaan muatan antara dalam dan luar sel mengakibatkan perbedaan potensial pada sel yang disebut dengan biopotensial. Biopotensial yang dapat diukur salah satunya adalah biopotensial mata. Pada penelitian ini, biopotensial mata diterapkan pada sistem kontrol aplikasi smartphone berbasis Android. Sistem kontrol tersebut dapat membantu penyandang tunadaksa dalam mengoperasikan smartphone. Sistem dirancang dengan komponen perangkat keras yang terdiri dari elektroda $\mathrm{Ag} / \mathrm{AgCl}$, penguat instrumentasi, Driven Right Leg (DRL), high pass filter, low pass filter, penguat non-inverting dan penguat penjumlah yang selanjutnya diproses menggunakan Arduino Uno dan dikirim ke smartphone dengan koneksi Bluetooth. Aplikasi android dibuat menggunakan App Inventor 2 berupa aplikasi Surah Yaasiin. Selanjutnya diukur batas nilai pergerakan mata ke kanan dan ke kiri pada lima orang subjek dengan menginstruksikan menggerakan mata ke kiri, lurus dan kanan. Nilai yang diperoleh untuk pergerakan mata ke kanan sebesar $\leq 1,87 \mathrm{~V}$ dan ke kiri sebesar $\geq 2,23 \mathrm{~V}$ yang selanjutnya dimasukkan dalam program arduino. Sistem selanjutnya diuji pada lima orang subjek dengan menghubungkan aplikasi ke Bluetooth rangkaian dan diamati respon pada aplikasi untuk menentukan nilai akurasi dan error dari sistem. Pengujian dilakukan dengan pengulangan tiap gerakan ke kanan dan ke kiri sebanyak 20 kali tiap subjek. Diperoleh akurasi rata-rata pergerakan mata ke kanan sebesar $84 \%$ dan ke kiri sebesar $86 \%$, sedangkan nilai rata-rata error untuk pergerakan mata ke kanan sebesar $16 \%$ dan ke kiri sebesar $14 \%$.
\end{abstract}

Kata kunci: Biopotensial, elektroda, mata, sistem kontrol, smartphone.

\begin{abstract}
The difference charge between the inside and outside of cells creates potential differences on the cells are called biopotentials. Biopotential that can be measured one of them is biopotential of the eye. In this research, biopotential of eye applied to the control system of smartphone app based on Android. The control system can help the disabled in operating the smartphone. The system is designed with hardware components consisting of $\mathrm{Ag} / \mathrm{AgCl}$ electrodes, instrumentation amplifier, Driven Right Leg (DRL), high pass filter, low pass filter, non-inverting amplifier and summing amplifier which are further processed using Arduino Uno and sent to the smartphone by the Bluetooth connection. The Android app created using App Inventor 2 is a Surah Yaasiin app. Further measured the value of the movement of the eye to the right and left on the five subject by instructing moving the eye to the left, straight and right. Values obtained for right eye movement of $\leq 1.87 \mathrm{~V}$ and to the left of $\geq 2.23 \mathrm{~V}$ are then included in the Arduino program. The system was further tested on five subjects by connecting the application to the Bluetooth of Circuit and observed the response on the application to determine the accuracy and error value of the system. The test is done by repeating each movement to the right and left as much as 20 times each subject. The accuracy of the average eye movement to the right is $84 \%$ and to the left $86 \%$, while the average error for the right eye movement is $16 \%$ and the left is $14 \%$.
\end{abstract}

Keywords: Biopotential, control system, electrode, eye, smartphone.

\section{PENDAHULUAN}

Tubuh manusia terdiri dari berbagai macam sistem salah satunya adalah sistem kelistrikan. Contoh sistem kelistrikan terjadi pada potensial listrik yang mengalir pada sel-sel saraf dan serat otot. Potensial listrik ini berasal dari aliran ion bermuatan masuk dan keluar sel sehingga terjadi perbedaan potensial antara luar dan dalam sel atau disebut dengan biopotensial (Cleveland Medical Device Inc, 2006). Biopotensial yang dapat diukur salah satunya biopotensial mata atau EOG (Elektrookulogram). 
Pada penelitian ini, biopotensial mata akan digunakan sebagai alat bantu penyandang tunadaksa untuk dapat mengontrol aplikasi pada smartphone berbasis android. Diharapkan dengan adanya sistem kontrol ini dapat membantu penyandang tunadaksa untuk dapat mengontrol aplikasi pada smartphone android.

\section{TINJAUAN PUSTAKA Biopotensial Mata}

Biopotensial pada tubuh manusia terdiri dari dua jenis yaitu resting potential dan action potential. Resting potential terjadi ketika akson sedang beristirahat, Natrium berada di luar sel dan Kalium berada di dalam sel. Terjadi perbedaan konsentrasi antara kalium dan natrium, konsentrasi kalium lebih tinggi dari natrium di dalam sel sementara kosentrasi natrium lebih tinggi dari kalium di luar sel. Perbedaan konsentrasi tersebut mengakibatkan terjadinya pemompaan natrium ke dalam dan kalium ke luar sel sehingga anion memberikan muatan negatif untuk menjaga keseimbangan. Sedangkan action potential terjadi ketika akson aktif, natrium berada di dalam sel dan kalium berada di luar sel. Action potential merupakan kebalikan dari resting potential (Namdev \& Siddiqui, 2015).

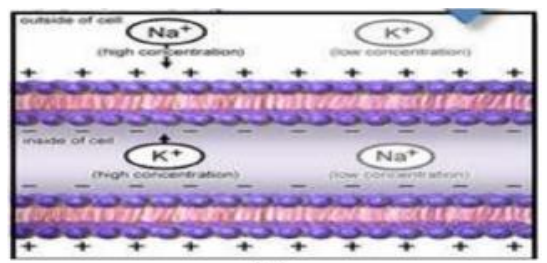

(a)

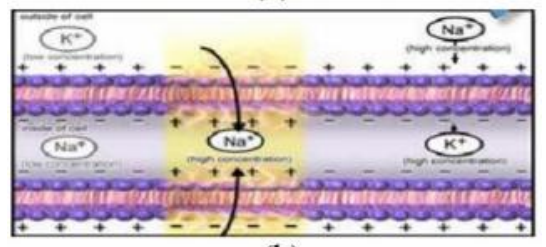

(b)

Gambar 1. (a) resting potential (b) action potential.

Beda potensial yang terjadi pada saat resting potential dapat direpresentasikan dengan persamaan Goldman :

$$
V=-\frac{k T}{q_{p}} \ln \left(\frac{p_{K}\left[\mathrm{~K}^{+}\right]_{i}+p_{\mathrm{Na}}\left[\mathrm{Na}^{+}\right]_{i}+p_{C l}\left[\mathrm{Cl}^{-}\right]_{o}}{p_{K}\left[\mathrm{~K}^{+}\right]_{o}+p_{\mathrm{Na}}\left[\mathrm{Na}^{+}\right]_{o}+p_{C l}\left[\mathrm{Cl}^{-}\right]_{i}}\right)
$$

Potensial yang terjadi bergantung pada temperatur $(T)$, muatan proton $\left(q_{p}\right)$, permeabilitas unsur $(P)$, dan konsentrasi dari tiap ion (Hadiyoso \& Rizal, 2015).

Pada elektrookulogram (EOG) sinyal biopotensial yang diterima merupakan resting potential dari mata yaitu antara kornea dan retina atau disebut dengan corneal retinal potential $(C R P)$. Mata memiliki dua kutub dengan kornea menjadi kutub positif sedangkan retina menjadi kutub negatif (Namdev \& Siddiqui, 2015). Hal ini digambarkan pada Gambar 2.

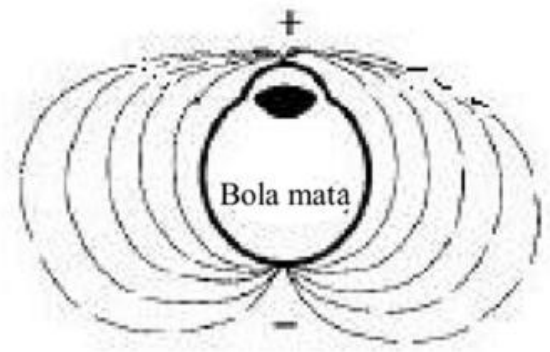

Gambar 2. Posisi kutub dan medan listrik mata

\section{Elektrookulografi}

Elektrookulografi merupakan salah satu teknik medis yang mana elektroda ditempatkan di dahi dekat mata untuk merekam gerakan mata. Gerakan mata dapat direkam dengan menempatkan elektroda di sebelah kiri dan kanan mata untuk mendeteksi gerakan horizontal atau di atas dan di bawah mata untuk mendeteksi gerakan vertikal (Namdev \& Siddiqui, 2015). Gerakan vertikal dari mata yang terbaik diukur pada bagian atas mata sedangkan untuk gerakan horizontal terbaik diukur pada tulang disisi mata (Hadiyoso \& Rizal, 2015). Penempatan elektroda dapat dilihat pada Gambar 3.

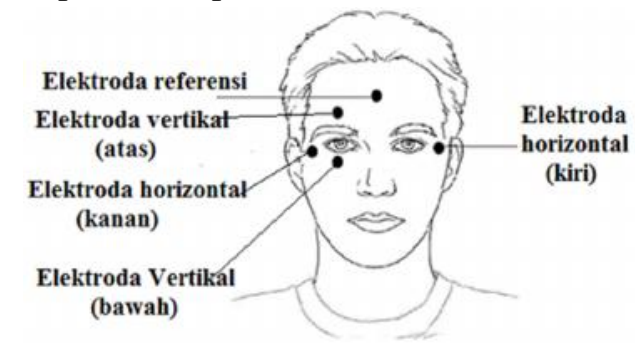


Gambar 3. Penempatan Elektroda

Mata digambarkan sebagai dipol tetap dengan kutub positif di kornea dan kutub negatif di retina. Ketika mata bergerak menuju salah satu elektroda, maka sisi positif dari retina menuju elektroda tersebut dan dan sisi negatif mata pada elektroda lainnya. Sinyal biopotensial mata berada pada kisaran frekuensi $0,1 \mathrm{~Hz}$ sampai 30 $\mathrm{Hz}$ (Constable et al., 2017)

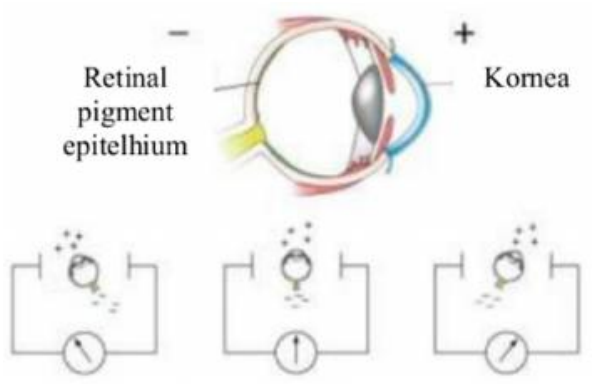

Gambar 4. Posisi kutub pada mata

\section{Elektroda}

Elektroda yang banyak digunakan sebagai alat penyadap sinyal biopotensial adalah elektroda $\mathrm{Ag} / \mathrm{AgCl}$ (Silver/Silver Chloride). Elektroda ini banyak digunakan karena pemakaian yang mudah dan handal. Selain itu, elektroda ini dapat digunakan pada suhu lebih dari $100^{\circ} \mathrm{C}$ (Suryanto, 2007).

Elektroda $\mathrm{Ag} / \mathrm{AgCl}$ ini kecil, mudah dibawa dan dapat digunakan pada berbagai penggunaan dan biasanya tidak mengkontaminasi media secara signifikan. Reaksi keseimbangan elektroda ini dapat ditulis sebagai berikut :

$$
\mathrm{AgCl} \leftrightarrow \mathrm{Ag}^{+}+\mathrm{Cl}^{-} \quad \mathrm{Ag}^{+}+\mathrm{e}^{-} \leftrightarrow \mathrm{Ag}
$$

Dari persamaan reaksi, dapat diketahui bahwa potensial elektroda bergantung pada aktivitas ion $\mathrm{Cl}^{-}$. Bentuk elektroda yang digunakan untuk EOG adalah seperti pada Gambar 5

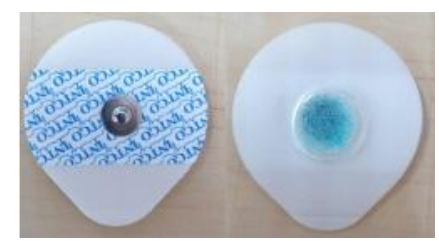

Gambar 5. Elektroda $\mathrm{Ag} / \mathrm{AgCl}$ untuk menyadap sinyal biopotensial
Konstruksi dari elektroda pada Gambar 5 dapat dilihat pada

Gambar 6.

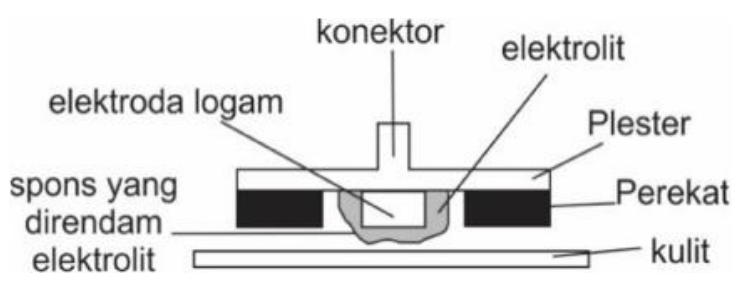

Gambar 6. Konstruksi elektroda $\mathrm{Ag} / \mathrm{AgCl}$

Model listrik dari antarmuka elektroda hingga kulit dapat digambarkan pada Gambar 7.

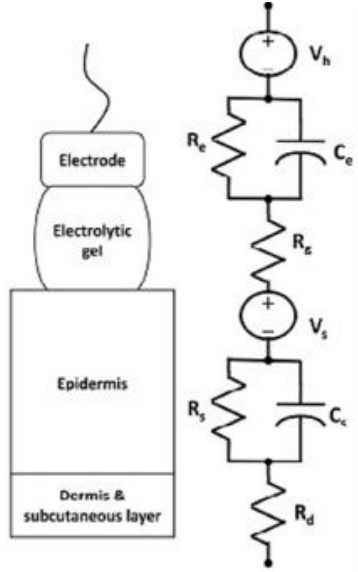

Gambar 7. Model listrik biopotensial pada permukaan kulit

Gambar 7 menggambarkan suatu model listrik dari antarmuka elektroda-kulit yang basah. Dalam model ini, $V h, R_{e}$ dan $C_{e}$ adalah half cell potential dari elektroda, resistensi dan kapasitansi. $R_{g}$ adalah resistansi efektif dari gel, $V_{s}$ adalah potensial karena semi-permeabilitas dari stratum korneum, lapisan atas epidermis; $R_{s}$ dan $C_{s}$ adalah resistensi dan kapasitansi dari lapisan epidermis dan $R_{d}$ adalah resistensi dari lapisan kulit yang lebih dalam (Fleury, Sugar, \& Chau, 2015).

\section{Penguat Diferensial}

Penguat diferensial merupakan suatu penguat dengan tegangan keluaran atau $V_{\text {out }}$ yang merupakan hasil selisih antara kedua buah tegangan masukan pada terminal inverting dan non-invertingnya (Bentley, 2005). Rumus umum 
yang berlaku untuk penguat diferensial adalah sebagai berikut :

$$
V_{\text {out }}=\frac{R_{F}}{R_{I N}}\left(V_{2}-V_{1}\right)
$$

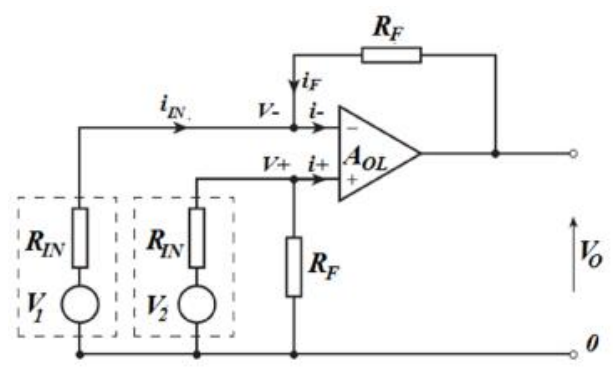

Gambar 8. Rangkaian Penguat Diferensial

\section{Penguat Instrumentasi}

Penguat instrumentasi adalah pengembangan dari penguat diferensial (selisih tegangan) yang mengakomodasi masukan selisih tegangan. Penguat instrumentasi dibangun oleh tiga buah op-amp. Op-amp 1 dan $2\left(\begin{array}{lll}A_{1} & \text { dan } & A_{2}\end{array}\right)$ dikonfigurasi sebagai penguat non-inverting, sedangkan op-amp ketiga $\left(A_{3}\right)$ dikonfigurasi sebagai penguat selisih tegangan. Penguat instrumentasi didesain dan harus memenuhi tegangan offset minimum, penguatan stabil, ketaklinieran rendah, input impedansi sangat tinggi, output impedansi sangat rendah, serta rasio penolakan modus bersama (common mode rejection ratio, CMRR) sangat tinggi (Bentley, 2005)

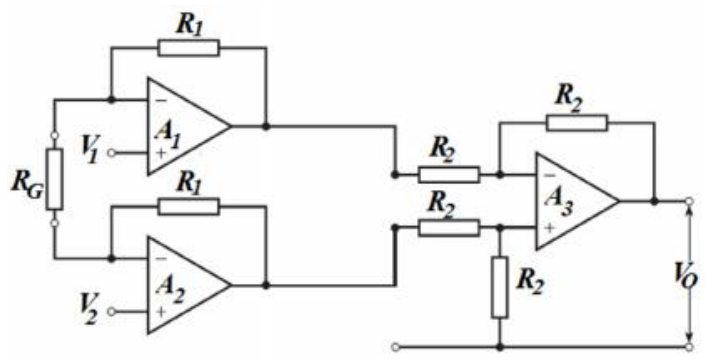

Gambar 9. Rangkaian Penguat Instrumentasi

Tegangan keluaran yang dihasilkan dari rangkaian Gambar 9 ditunjukkan pada persamaan berikut:

$$
V_{\text {out }}=\left(1+\frac{2 R_{1}}{R_{g}}\right)\left(V_{2}-V_{1}\right)
$$

Sedangkan penguatannya dirumuskan sebagai :

$$
A=\left(1+\frac{2 R_{1}}{R_{g}}\right)
$$

\section{Penguat Tak Membalik}

Penguat tak membalik merupakan rangkaian untuk menguatkan tegangan dengan keluaran memiliki fasa yang sama dengan masukannya (Bentley, 2005). Tegangan keluaran dari rangkaian ini sebagai berikut :

$$
V_{\text {out }}=\left(\frac{R_{f}}{R_{1}}+1\right) V_{\text {in }}
$$

Sedangkan penguatannyanya dapat dituliskan sebagai berikut :

$$
A_{V}=\left(\frac{R_{f}}{R_{1}}\right)+1
$$

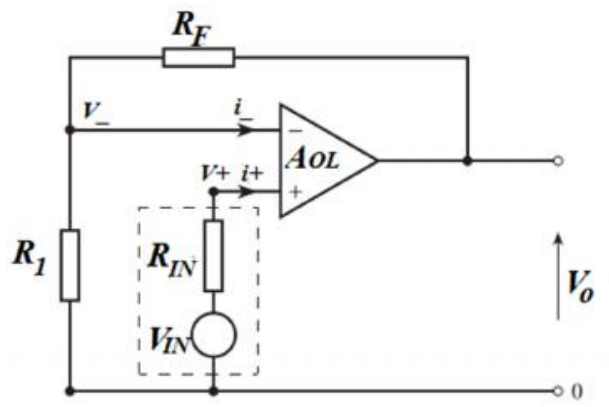

Gambar 10. Rangkaian Penguat tak membalik

\section{Penguat Penjumlah}

Rangkaian adder atau penjumlah sinyal menggunakan konfigurasi Op-Amp sebagai penguat dengan input lebih dari satu untuk menghasilkan nilai keluaran yang linier dengan hasil penjumlahan sinyal input dan faktor penguatannya. Dasarnya, rangkaian ini tersusun dari penguat membalik atau tak membalik yang diberi input lebih dari satu (Bentley, 2005).

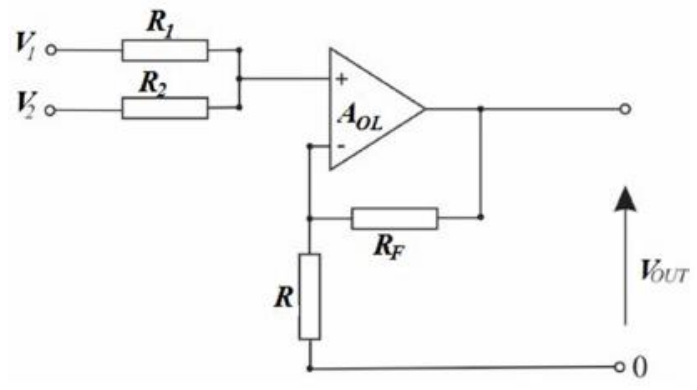

Gambar 11. Penguat penjumlah tak membalik 
Rangkaian penjumlah tak membalik memiliki penguatan yang tidak melibatkan resistansi input yang digunakan. Sehingga sebaiknya nilai resistansi inputnya bernilai sama agar hasil penjumlahan stabil dan akurat. Penguatan dari rangkaian ini sama seperti persamaan (6) sedangkan keluarannya sebagai berikut :

$$
V_{\text {out }}=\left(\frac{R_{f}}{R}+1\right) \cdot\left(\frac{R_{2}}{R_{1}+R_{2}} V_{1}+\frac{R_{1}}{R_{1}+R_{2}} V_{2}\right)
$$

Ketika nilai $R_{I}=R_{2}=R$ maka

$$
V_{\text {out }}=\left(\frac{R_{f}}{R}+1\right) \cdot\left(\frac{V_{1}+V_{2}}{2}\right)
$$

\section{Filter}

Frekuensi biopotensial mata berada pada rentang $0,1 \mathrm{~Hz}$ sampai dengan $30 \mathrm{~Hz}$ (Constable et al., 2017). Sehingga frekuensi di luar rentang tersebut perlu diredam karena dapat mengakibatkan noise. Tapis lolos tinggi diperlukan untuk meredam frekuensi yang rendah dan meloloskan frekuensi yang tinggi yaitu di atas $0,1 \mathrm{~Hz}$. Sedangkan tapis lolos rendah diperlukan untuk meredam frekuensi yang tinggi dan meloloskan frekuensi yang rendah yaitu di bawah $30 \mathrm{~Hz}$. Frekuensi cut-off dari filter adalah :

$$
f_{c}=\frac{1}{2 \pi R C}
$$

\section{Tapis Lolos Tinggi (High Pass Filter)}

Tapis lolos tinggi merupakan suatu rangkaian yang akan melewatkan isyarat yang berada diatas frekuensi cut-off dan akan menahan isyarat yang berada dibawah frekuensi cut-off. Sinyal input dilewatkan pada rangkaian seri Kapasitor $(C)$ dan Resistor $(R)$. Rangkaian HPF ditunjukkan pada Gambar 12.

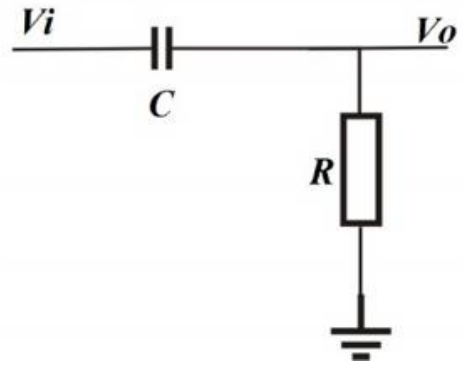

\section{Gambar 12. Tapis Lolos Tinggi}

Dari terjadi bagi tegangan antara $C$ dan $R$. Gain dari rangkaian tapis lolos tinggi ini adalah

$\frac{V_{\text {out }}}{V_{\text {in }}}=\frac{Z_{R}}{Z_{R}+Z_{C}}=\frac{R}{R-j \frac{1}{\omega C}}=\frac{1}{1-j \frac{1}{\omega C R}}$

Pada saat frekuensi tinggi, maka $\omega$ sangatlah besar sehingga $j \frac{1}{\omega C R}$ sangat kecil dari 1, sehingga gain dari rangkaian akan mendekati 1. Sedangkan pada saat frekuensi rendah maka gain akan mengecil (Storey, 2009). Grafik respon gain dari frekuensi pada tapis lolos tinggi dapat dilihat pada Gambar 12.

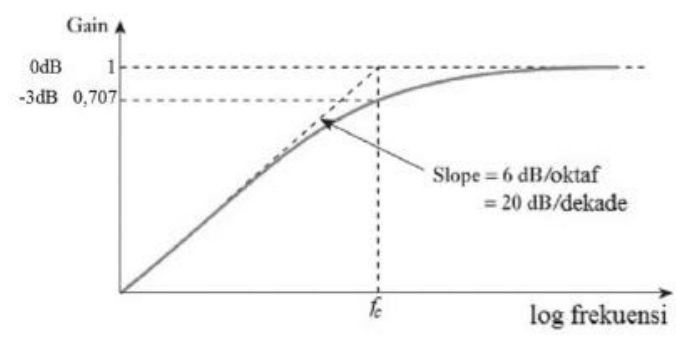

Gambar 13. Respon gain tapis lolos tinggi

\section{Tapis Lolos Rendah (Low Pass Filter)}

Tapis lolos rendah yang digunakan adalah tapis aktif yang keluarannya akan tetap ketika diberi beban sehingga tidak mengurangi tegangan sebelumnya. Tapis lolos rendah yang akan digunakan adalah tapis lolos rendah butterworth. Filter Butterworth tersusun dari tapis lolos rendah pasif dan penguat operasional.

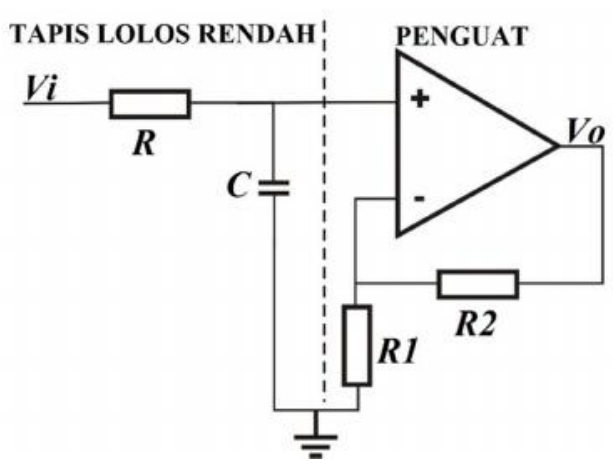

Gambar 14. Low Pass Filter Butterworth 
Pada rangkaian tapis lolos rendah pasif terjadi bagi tegangan antara $R$ dan $C$ dan yang memasuki penguat adalah tegangan dari kapasitor. Gain dari tegangan pada rangkaian low pass filter adalah

$$
\frac{V_{\text {out }}}{V_{\text {in }}}=\frac{Z_{C}}{Z_{R}+Z_{C}}=\frac{-j \frac{1}{\omega C}}{R-j \frac{1}{\omega C}}=\frac{1}{1+j \omega C R}
$$

Pada saat frekuensi rendah, maka $\omega$ sangatlah kecil sehingga $j \omega C R$ sangat kecil dari 1, sehingga gain dari rangkaian akan mendekati 1 . Sedangkan pada saat frekuensi tinggi maka gain akan mengecil (Storey, 2009).

Hasil tanggapan frekuensi filter butterworth ini datar pada daerah passband dan redaman yang meningkat secara monotikal pada stopband. Oleh karena itu, low pass filter Butterworth sering digunakan sebagai anti aliasing filter dalam aplikasi konverter data dimana tingkat sinyal yang tepat diperlukan di seluruh sinyal passband.

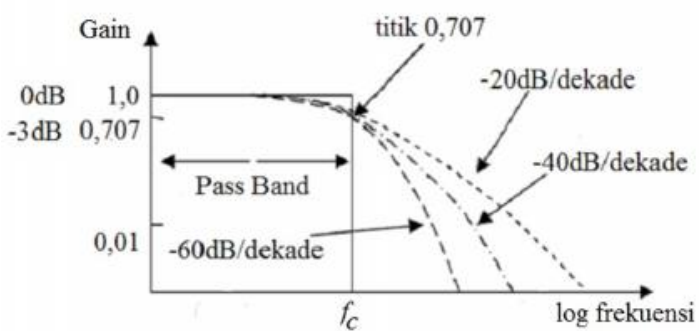

Gambar 15. Respon frekuensi LPF Butterworth

Gambar 15 menunjukkan respon ideal (garis solid) dan praktikal (garis putus-putus) frekuensi dari filter butterworth. Karakteristik dari sebuah Filter butterworth tidak didesain untuk menyimpan sudut fasa konstan pada frekuensi cut-off. pada frekuensi cut-off mengalami pelemahan sebesar $-3 \mathrm{~dB}$ dan frekuensi diatas frekuensi cut-off mengalami pelemahan menjadi -20dB/dekade/orde (Hidayat, 2012).

\section{Driven Right Leg (DRL)}

Rangkaian Driven Right Leg (DRL) merupakan rangkaian yang digunakan pada instrumen EKG untuk mengurangi noise yang berasal dari tubuh dan juga untuk sistem pengaman pasien. Dinamai dengan Driven Right Leg karena elektroda yang terhubung pada rangkaian ini adalah elektroda pada kaki kanan yang merupakan elektroda referensi pada EKG. Rangkaian ini juga dapat digunakan pada pengukuran EOG untuk memperoleh fungsi yang sama.

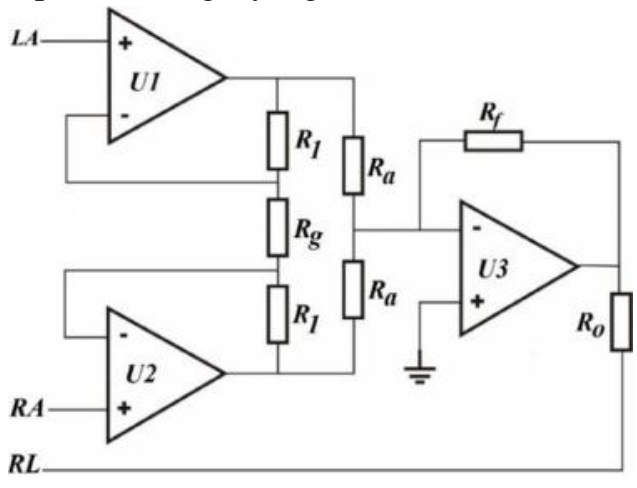

Gambar 16. Rangkaian Driven Right Leg

Elektroda kaki kanan terhubung pada keluaran Op-Amp. Tegangan common-mode pada tubuh dirasakan oleh rata-rata kedua resistor $R_{a}$, terbalik, diperkuat dan diumpankan kembali ke kaki kanan. Umpan negatif ini menjadikan tegangan common-mode bernilai rendah. Arus pada tubuh tidak mengalir ke ground melainkan ke

keluaran

Op-Amp. Hal tersebut berguna untuk mereduksi interferensi selama terhubung ke penguat biopotential dan efektif meng-ground-kan pasien (Webster, 2009).

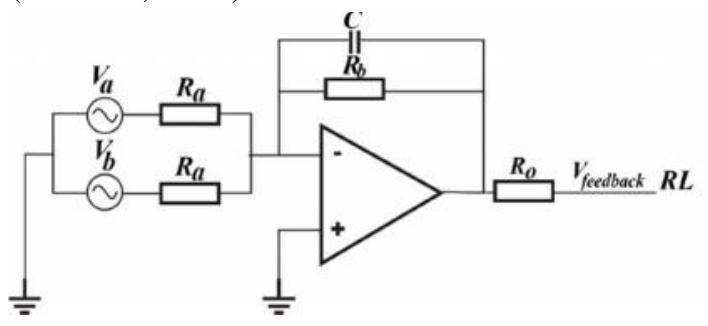

Gambar 17. Rangkaian Driven Right Leg dengan kapasitor

Pada gambar dapat memperkecil penguatan common mode pada rangkaian penguat biopotensial. Sinyal common mode dideteksi dan dikuatkan dengan faktor feedback dan diumpan balik negatif ke tubuh. Dengan faktor feedback yang besar, maka sinyal common-mode akan mengecil. Fungsi dari kapasitor $C$ pada rangkaian adalah untuk mengurangi noise akibat frekuensi tinggi (Gunawan, 2011). Dengan prinsip thevenin maka, rangkaian Gambar 17 dapat diubah menjadi rangkaian Gambar 18 dengan 
$V_{\text {thevenin }}=\left(V_{a}+V_{b}\right) / 2, R_{\text {thevenin }}=R_{a} / 2$ dan $R f=Z_{C} / / R_{b}$.

Sehingga

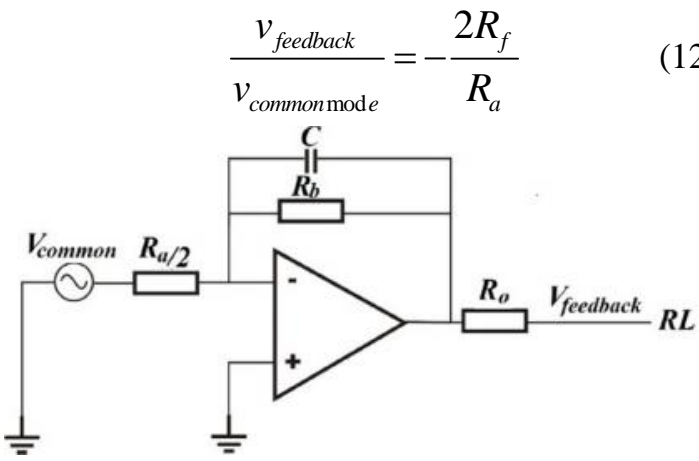

Gambar 18. Rangkaian ekuivalen driven right leg dengan Kapasitor

\section{METODE}

\section{Perancangan dan Perangkaian Sistem}

Pada tahap ini sistem dirancang dan dirangkai sesuai dengan diagram blok yang ditunjukkan

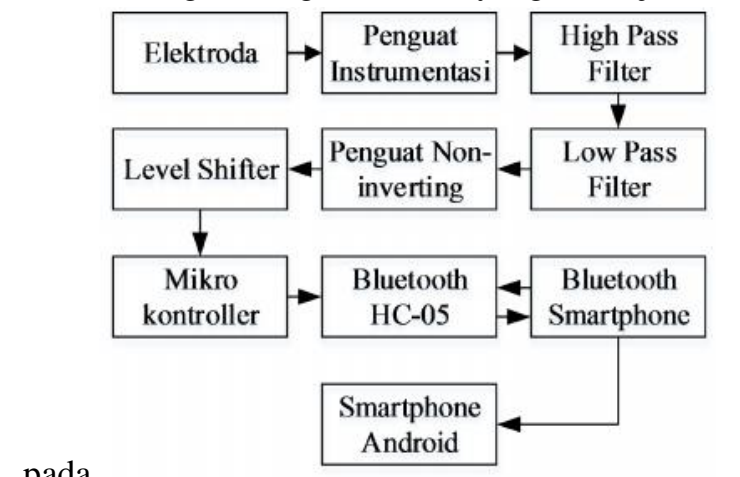

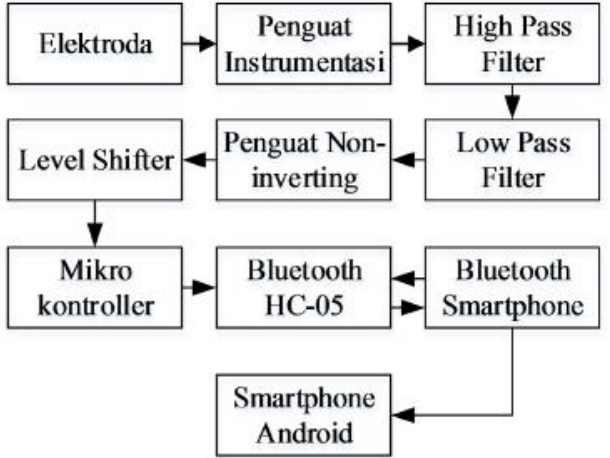

Gambar 19. Diagram blok Sistem

Tegangan yang diukur merupakan biopotensial mata yang telah melewati rangkaian pengkondisi sinyal. Data diambil pada mata lima orang subjek dengan menginstruksikan menggerakan matanya ke arah kanan dan kiri serta lurus secara berulang-ulang. Selanjutnya data dianalisis sehingga diperoleh nilai batas tegangan pergerakan mata ke kanan dan ke kiri yang selanjutnya dimasukkan ke dalam program pada arduino.

\section{Pembuatan Program Mikrokontroller}

Program dibuat dengan menggunakan software Arduino IDE. Adapun diagram alir pemrogram tersebut ditunjukkan pada Gambar 20.

\section{Gambar 19.}

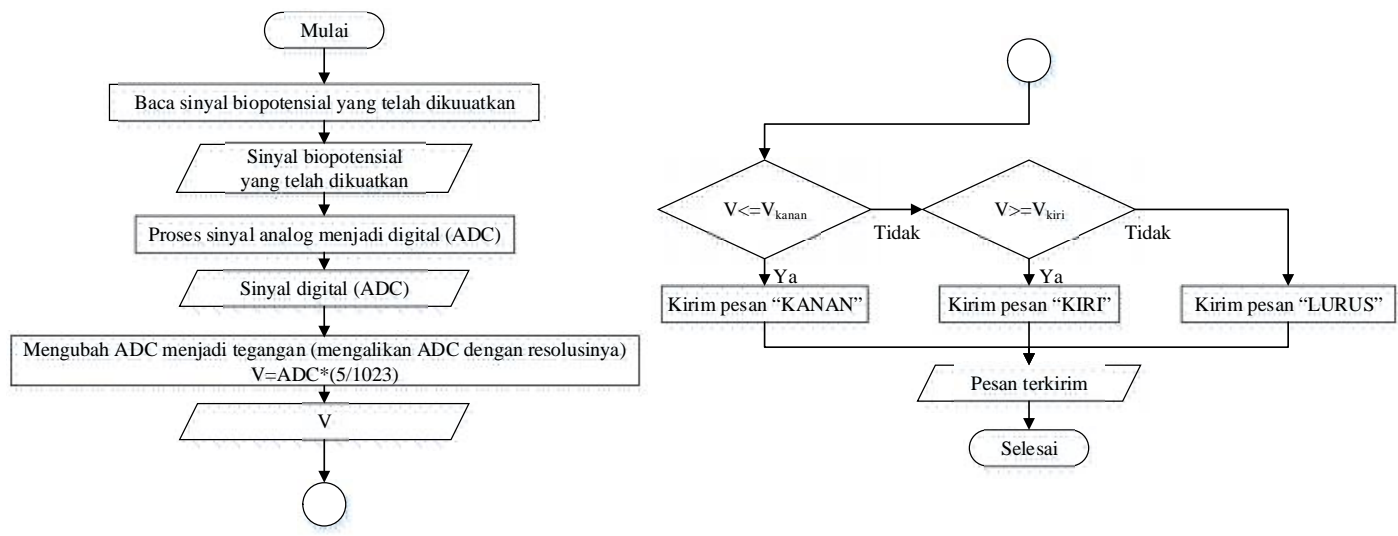

Gambar 20. Diagram Alir Program Mikrokontroller

\section{Pembuatan Aplikasi Android}

Aplikasi android yang dibuat adalah aplikasi buku surah Yaasiin. Aplikasi dibuat dengan menggunakan App inventor 2. Pembuatan aplikasi dapat dilakukan secara online di http://appinventor.mit.edu/. Koneksi aplikasi 
di-setting sebagai Bluetooth client dan dapat menerima pesan dari perangkat Bluetooth lainnya. Pesan yang diterima digunakan sebagai perintah untuk membuka halaman selanjutnya dan halaman sebelumnya. Selain itu, aplikasi ini dapat digunakan tanpa terhubung ke sistem kontrol yaitu dengan cara menyapukan jari pada layar ke arah kiri untuk membuka halaman selanjutnya dan ke arah kanan untuk membuka halaman sebelumnya seperti membuka halaman buku. Adapun diagram alir pemrogramannya ditunjukkan pada Gambar 21.

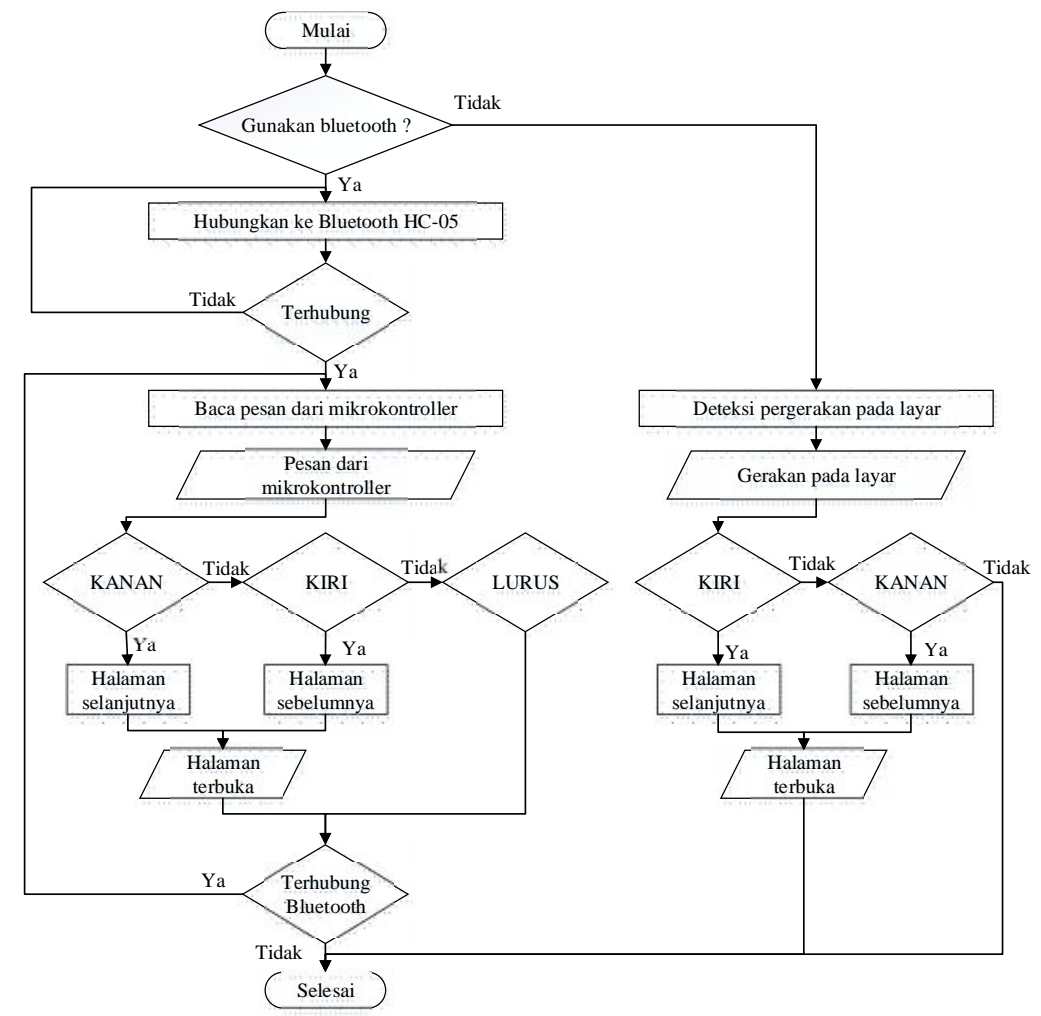

Gambar 21. Diagram Alir Aplikasi Android

\section{Pengujian Sistem}

Tahap ini sistem telah selesai dirangkai dan siap untuk diuji. Pengujian dilakukan pada mata lima orang subjek dengan rangkaian yang sudah terhubung dengan android. Mata digerakkan ke kanan dan ke kiri dengan pengulangan 20 kali tiap gerakan tiap subjek. Respon yang terjadi pada aplikasi android dicatat.

\section{HASIL DAN PEMBAHASAN Perancangan dan Perangkaian Sistem}

Tahap ini dibagi menjadi beberapa bagian yaitu perancangan sistem, pembuatan skema rangkaian, pemilihan komponen, pembuatan layout PCB, etching $\mathrm{PCB}$, pengeboran dan pemasangan komponen. Sistem dirancang sesuai

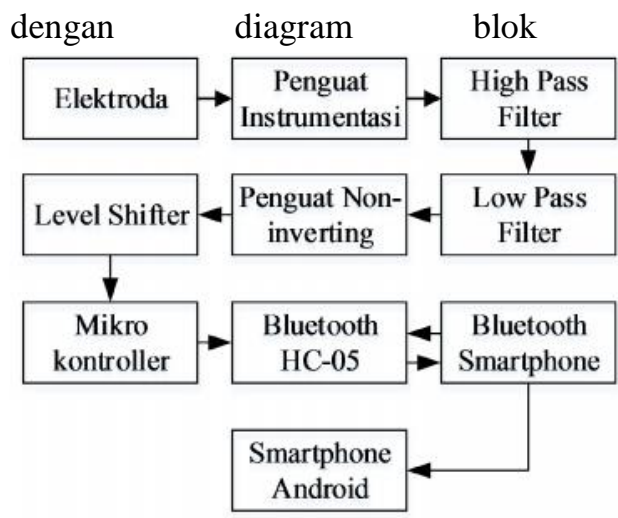

Gambar 19 dan selanjutnya pembuatan skema rangkaian untuk input hingga level shifter sebagai rangkaian pengkondisi sinyal seperti pada Gambar 22. 


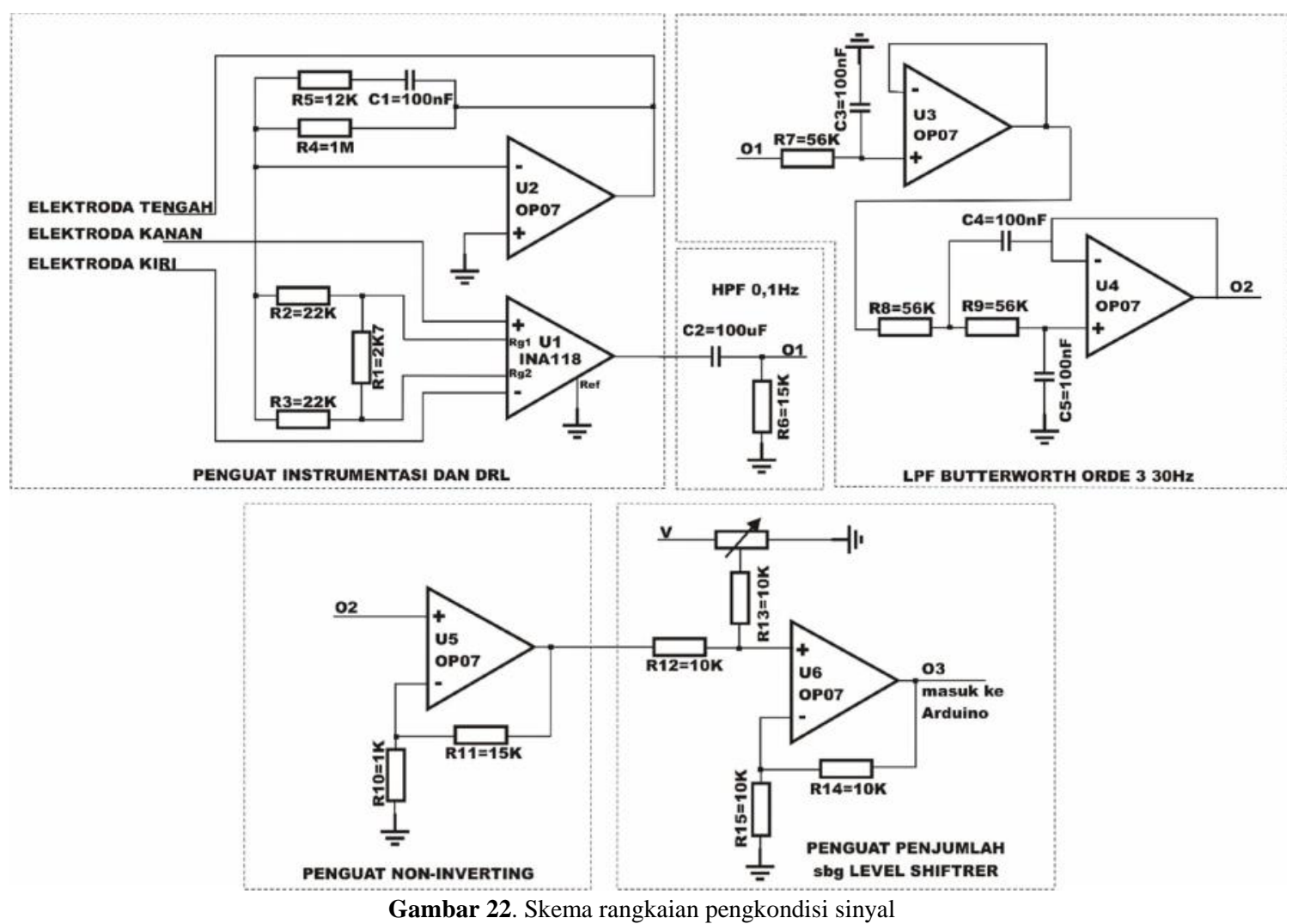

Rangkaian pengkondisi sinyal dirancang dengan penguatan penguat instrumentasi sebesar $20 \mathrm{kali}$ dan elektroda referensi terhubung dengan rangkaian $D R L$. Filter HPF yang digunakan adalah filter pasif dengan frekuensi cut-off 0,1 $\mathrm{Hz}$ dan LPF dengan filter aktif tipe Butturwoth dengan topologi sallen-key Orde 3 dengan frekuensi cut-off $30 \mathrm{~Hz}$. Penguat non-inverting dirancang dengan penguatan $15 \mathrm{kali}$ dan penguat penjumlah dengan penguatan 1 kali dengan tegangan tambahan sebesar $1 \mathrm{~V}$.

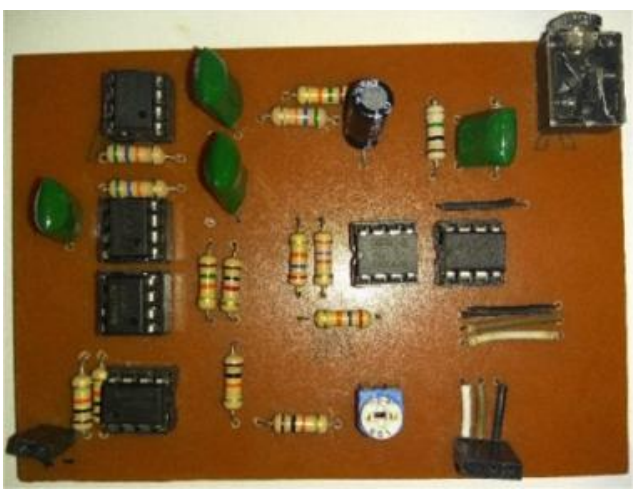

Gambar 23. Rangkaian Pengkondisi sinyal
Rangkaian yang telah dirancang selanjutnya dibuat pada PCB. Pembuatan rangkaian pada PCB terdiri dari beberapa tahap diantaranya pembuatan layout PCB menggunakan software sprint layout 6.0. Selanjutnya layout diaplikasikan pada PCB dengan teknik gosok menggunakan lotion dan selanjutnya di-etching dengan menggunakan larutan $\mathrm{FeCl}_{3}$. $\mathrm{PCB}$ yang telah di-etching selanjutnya dibor dan komponen dipasang. Hasil rangkaian yang telah dibuat dapat dilihat pada Gambar 23.

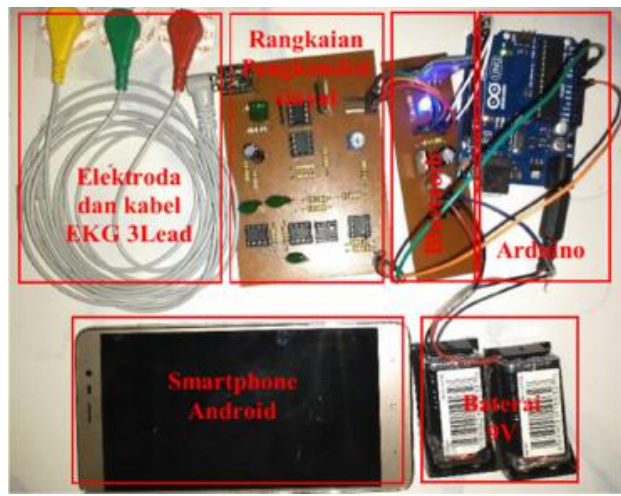

Gambar 24. Sistem Kontrol 
Keluaran dari rangkaian pengkondisi sinyal selanjutnya akan diolah dengan menggunakan mikrokontroller arduino uno yang terhubung dengan pin pembacaan sinyal analog dan ground. Selanjutnya hasil pengolahan oleh mikrokontroller akan dikirim dengan menggunakan Bluetooth HC-05 yang memiliki tegangan kerja untuk pin RX sebesar $3,3 \mathrm{~V}$ sehingga dibutuhkan rangkaian pembagi tegangan dari PIN TX arduino ke PIN RX Bluetooth. Dikarena PIN TX arduino memiliki tegangan sebesar $5 \mathrm{~V}$, maka dibutuhkan resistor sebesar $1 \mathrm{~K}$ dan $2 \mathrm{~K}$ untuk membagi tegangannya. Sistem Kontrol lengkap dapat dilihat pada Gambar 24.

\section{Pengambilan Data Tegangan}

Data yang diambil adalah tegangan yang berasal dari biopotensial mata telah melewati rangkaian pengkondisi sinyal. Biopotensial mata diukur dengan menggunakan NI USB-6009 dan direkam dengan menggunakan software Data Logging and Monitoring. Subjek penelitian yang digunakan sebanyak lima orang.

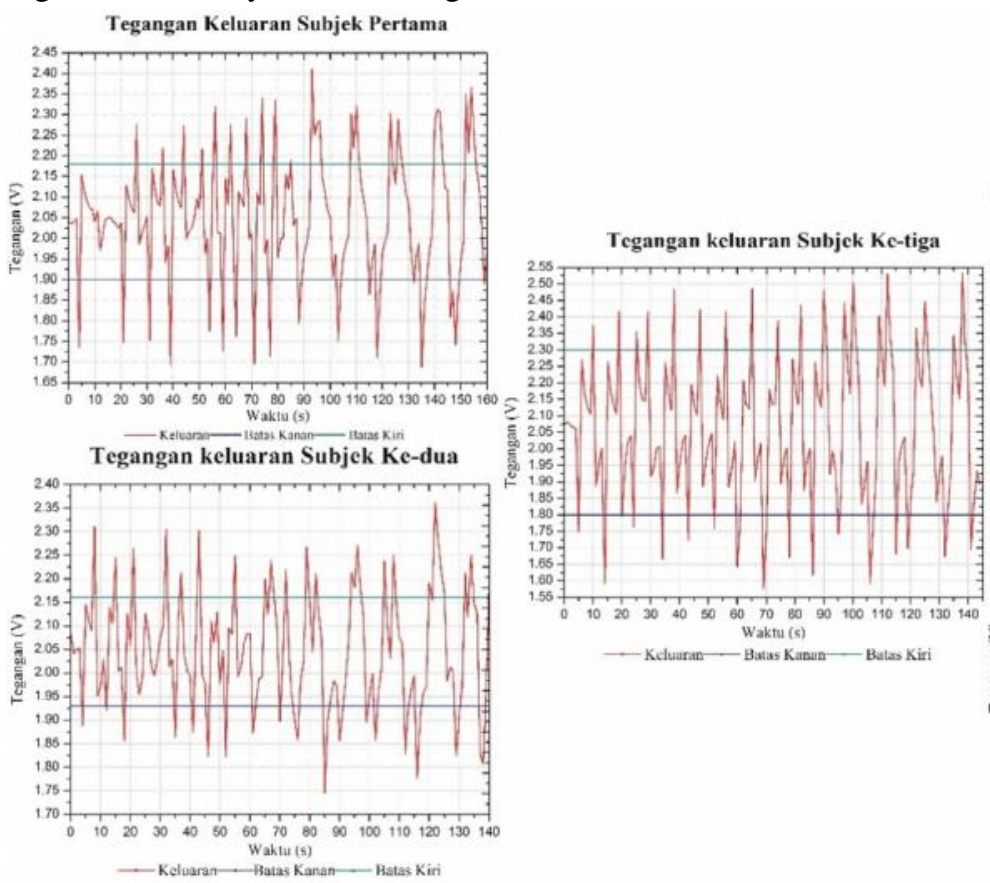

Gambar 25. Tegangan keluaran tiap subjek
Tegangan keluaran yang telah melewati rangkaian pengkondisi sinyal dapat dilihat pada Gambar 25. Pada grafik, untuk puncak merupakan pergerakan mata kearah kiri dan lembah merupakan pergerakan mata ke kanan. Pengambilan data dilakukan dengan dua keadaan dimana saat pergerakan ke kanan dan ke kiri ditahan selama satu detik dan lima detik. Pada grafik, lima puncak dan lima lembah terakhir merupakan pergerakan mata yang ditahan selama lima detik. Dari rekaman data pengukuran melalui software Data Logging and Monitoring ditentukan waktu yang terbaik dalam pergerakan mata, dilihat dari nilai pergerakan mata apabila bergerak ke kiri maka nilai setelahnya tidak menunjukkan seperti bergerak ke arah kanan atau sebaliknya. Waktu pergerakan terbaik yang diperoleh adalah 0,98 detik. Sehingga pada grafik ditentukan batas pergerakan mata yang disesuaikan ketika ditahan selama satu detik. Batas pergerakan mata ditentukan secara visual dengan memperhatikan respon dari setiap pergerakan.

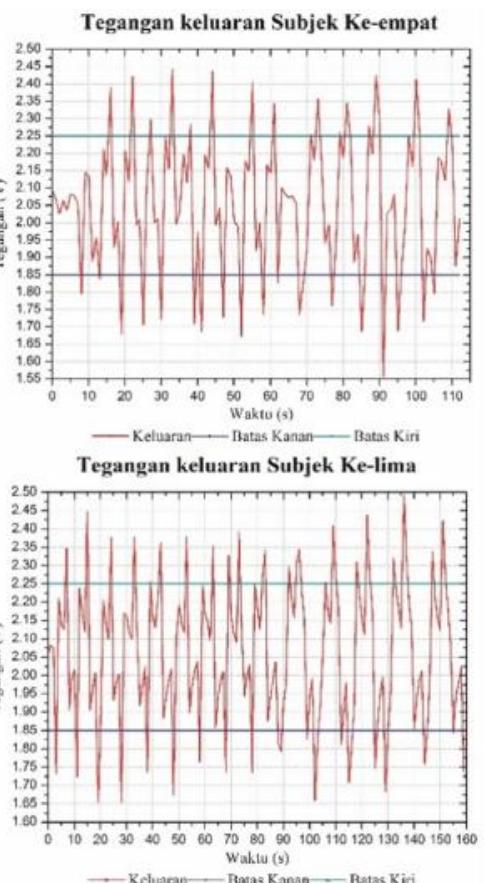

- Keluaran- Baxas Kanan - Ratas Kii

Dari grafik pada Gambar 25 diperoleh batasbatas pergerakan mata untuk tiap subjek yang dapat dilihat pada

Tabel 1 
Tabel 1. Batas pergerakan mata tiap subjek dalam satuan Volt

\begin{tabular}{|l|l|l|}
\hline Subjek ke- & Batas Kanan & Batas Kiri \\
\hline 1 & 1,90 & 2,18 \\
\hline 2 & 1,93 & 2,16 \\
\hline 3 & 1,80 & 2,30 \\
\hline 4 & 1,85 & 2,25 \\
\hline 5 & 1,85 & 2,25 \\
\hline Rata-rata & 1,87 & 2,23 \\
\hline
\end{tabular}

Batas pergerakan mata rata-rata yang diperoleh dari setiap subjek untuk pergerakan mata ke kanan adalah $\leq 1,87 \mathrm{~V}$ dan pergerakan ke kiri adalah $\geq 2,23 \mathrm{~V}$. Nilai batas yang diperoleh ini selanjutnya digunakan pada pemrograman mikrokontroller arduino uno.

\section{Pembuatan Program Mikrokontroller}

Program yang dibuat dalam penelitian ini adalah program untuk mengirim pesan arah pergerakan mata melalui Bluetooth. Program dibuat menggunakan software arduino IDE dengan bahasa pemrograman C. Program ini menggunakan fungsi if untuk menentukan arah pergerakan mata dengan batas nilai yang telah diperoleh pada tahap sebelumnya.

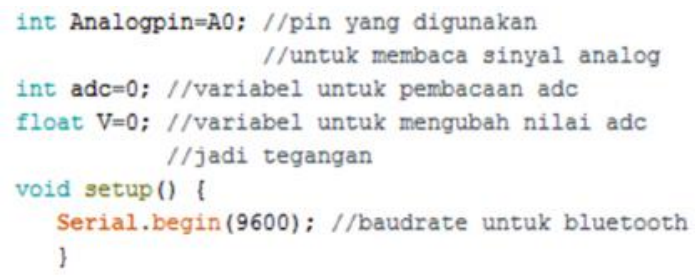

Gambar 26. Inisiasi dan void setup program arduino

Bagian inisiasi program ini adalah pembacaan input analog yang berasal dari pin $A O$ pada arduino uno dan variabel $a d c$ dengan nilai awal 0 yang keduanya merupakan bilangan integer (bulat) serta variabel $V$ dengan nilai awal 0 yang merupakan bilangan float (desimal). Selanjutnya pada void setup merupakan bagian yang akan dieksekusi sekali saja pada awal program berjalan, terdapat pengaturan baudrate untuk komunikasi serial. Pada program ini digunakan baudrate $9.600 \mathrm{bps}$. Nilai ini merupakan nilai standar pada komunikasi serial karena tidak terlalu lambat dan tidak terlalu cepat karena apabila terlalu cepat dapat mengakibatkan noise. Nilai baudrate ini harus sama dengan piranti yang akan dikomunikasikan seperti pada Bluetooth atau serial monitor dan serial plotter pada arduino IDE.

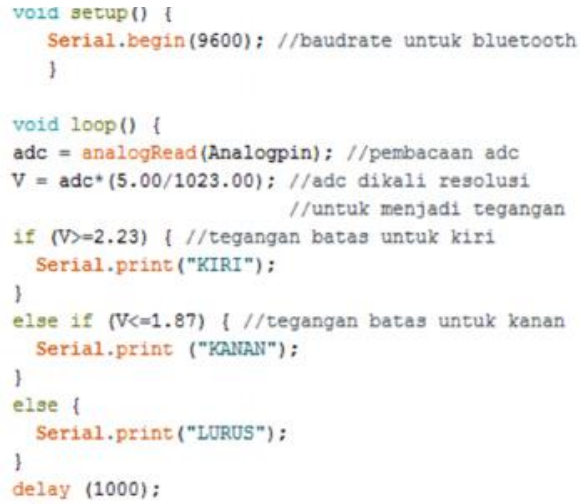

Gambar 27. Void loop program arduino

Bagian void loop merupakan bagian yang akan diulang terus menerus selama arduino menyala. Terdapat perintah pembacaan input analog yang disimpan pada variabel $a d c$. Selanjutnya, nilai adc yang diperoleh diubah menjadi nilai tegangan dengan cara mengalikan nilai $a d c$ dengan resolusi adc 10 bit pada arduino dengan tegangan referensi $5 \mathrm{~V}$. Setelah diperoleh nilai tegangan, selanjutnya nilai tegangan tersebut dibandingkan dengan nilai batas arah pergerakan mata ke kanan atau ke kiri menggunakan fungsi logika if. Jika nilai pembacaan lebih dari 2,23V maka arduino akan mengirimkan pesan "KIRI" dan jika nilai pembacaan kurang dari $1,87 \mathrm{~V}$ maka arduino akan mengirim pesan "KANAN" selain itu apabila nilai pembacaan bukan keduanya maka arduino akan mengirim pesan "LURUS". Perulangan dilakukan dengan jeda atau delay selama $1000 \mathrm{~ms}$ atau $1 \mathrm{~s}$.

\section{Pembuatan Aplikasi Android}

Aplikasi android yang dibuat adalah aplikasi buku surah Yaasiin. Aplikasi dibuat dengan menggunakan App inventor 2. Pembuatan aplikasi dilakukan secara online di http://appinventor.mit.edu/. Fungsi-fungsi pada App inventor 2 berupa blok-blok perintah 
seperti puzzle sehingga memudahkan pengguna untuk membuat program karena apabila tidak sesuai atau bukan pasangannya tidak akan dapat terhubung.

Aplikasi surah Yaasiin pada penelitian ini dapat dikontrol dengan menggunakan sistem kontrol yang telah dibuat atau secara manual dengan menyapu layar ke kanan atau kiri tanpa koneksi Bluetooth. Sehingga aplikasi ini dapat digunakan oleh penyandang tunadaksa atau orang normal. Pada program ini terdapat beberapa bagian diantaranya blok inisiasi, blok untuk menghubungkan dengan Bluetooth, blok penerimaan pesan dan blok peggunaan aplikasi secara manual.

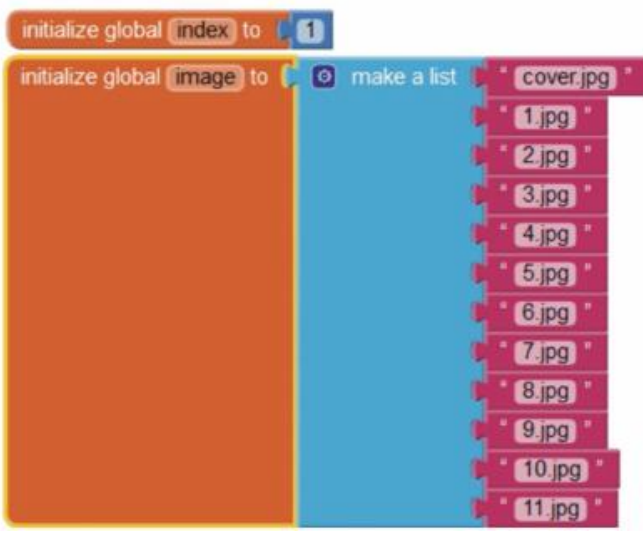

Gambar 28. Blok program inisiasi

Blok pertama adalah blok inisiasi yang ditunjukkan pada Gambar 28. Pada blok ini diinisiasikan global index dan global image. Pada global index diinisiasikan dengan nilai satu dan selanjutnya global index dapat berubah bergantung dari keadaan pada blok selanjutnya. Pada global image diinisiasikan urutan atau daftar gambar dari halaman-halaman surah Yaasiin, terdapat cover dan isi dengan jumlah sebelas halaman.

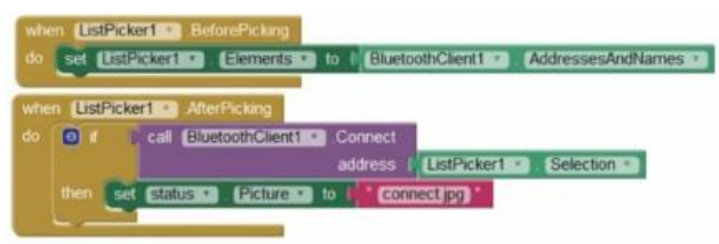

Gambar 29. Blok program koneksi Bluetooth

Blok ke-dua merupakan blok program untuk koneksi Bluetooth yang ditunjukkan pada
Gambar 29. Pada blok ini terdapat ListPickerl yaitu tombol yang selanjutnya akan menampilan daftar piranti Bluetooth yang aktif disekitar smartphone. Pada Before Picking akan menampilkan Bluetooth yang aktif dan pada after picking yaitu setelah memilih piranti Bluetoothnya maka Bluetooth client akan dihubungkan dengan piranti yang dipilih dan apabila terhubung maka gambar status koneksi akan berubah menjadi terhubung.

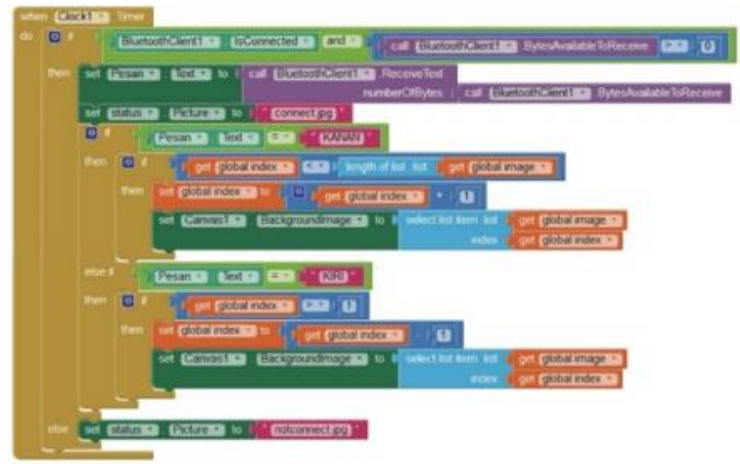

Gambar 30. Blok program penerimaan pesan Bluetooth

Blok ke-tiga adalah blok penerimaan pesan Bluetooth yang ditunjukkan pada Gambar 30 . Pada blok ini menggunkan clock timer, timer ini berfungsi seperti delay yaitu untuk memberi jeda penerimaan pesan melalui Bluetooth, pada program ini digunakan delay satu detik karena pada program arduino menggunakan delay satu detik juga. Nilai delay program aplikasi android dengan program pengiriman pesan pada arduino harus sama agar pesan yang dikirim akan langsung diterima oleh aplikasi android. Jika Bluetooth terhubung dan jumlah bit yang diterima lebih besar dari 0 maka pesan yang diterima akan disimpan pada label "Pesan" dan status koneksi akan terhubung, jika tidak menerima pesan apapun maka status koneksi akan terpustus. Pesan yang diterima selanjutnya akan dibandingkan dengan menggunakan fungsi logika if. Jika pesan yang diterima adalah "KANAN" maka akan dieksekusi fungsi logika if selanjutnya yaitu untuk mengubah gambar. Jika nilai global index kurang dari posisi gambar pada global image maka nilai global index akan ditambahkan satu dan background gambar pada canvasl akan diubah menjadi posisi global image sesuai nilai global index pada saat ini. Jika 
pesan yang diterima adalah "KIRI", maka jika global index lebih besar dari satu maka nilai global index akan dikurangi satu dan background canvas1 akan diubah menjadi posisi global image sesuai nilai global index pada saat ini.

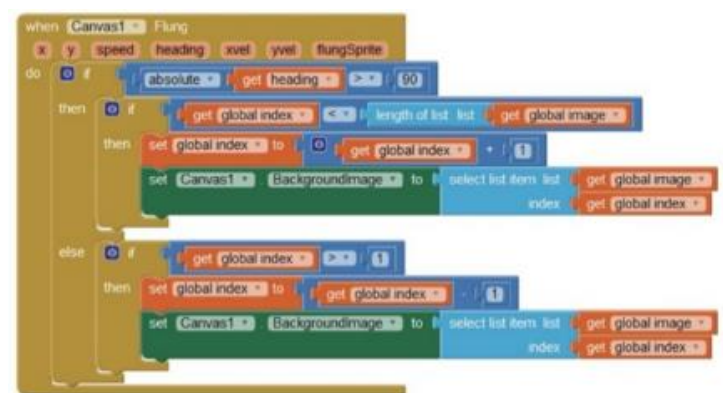

Gambar 31. Blok program penggunaan aplikasi secara manual

Blok ke-empat adalah blok yang berfungsi untuk menjalankan aplikasi tanpa koneksi Bluetooth atau tidak menggunakan biopotensial mata. Blok program ditunjukkan pada Gambar 31. Blok ini digunakan untuk pengguna aplikasi yang merupakan orang normal atau tidak memiliki sistem kontrol. Blok ini memungkinkan pengguna hanya dengan menyapukan jarinya pada layar ke arah kiri atau kanan untuk mengganti halaman. Ketika canvasl disapu dengan jari dan jika besar sudut absolut yang terbentuk dari titik pertama jari menyentuh layar dan titik akhir membentuk sudut lebih dari $90^{\circ}$ atau disapukan ke arah kiri, maka jika nilai global index kurang dari posisi gambar pada global image maka nilai global index akan ditambahkan satu dan background gambar pada canvasl akan diubah menjadi posisi global image sesuai nilai global index pada saat ini. Selain itu, jika nilai global index kurang dari posisi gambar pada global image maka nilai global index akan ditambahkan satu dan background gambar pada canvas1 akan diubah menjadi posisi global image sesuai nilai global index pada saat ini.

\section{Pengujian Sistem}

Setelah sistem kontrol dirangkai dan batas pergerakan mata ke kiri dan kanan telah dimasukkan kedalam mikrokontroller, selanjutnya sistem diuji dengan menghubungkan smartphone android dengan aplikasi surah Yaasiin yang telah di-install terlebih dahulu. Sistem diuji pada lima subjek dengan menginstruksikan subjek menggerakan mata ke kiri dan ke kanan. Respon sistem dilihat pada aplikasi Surah Yaasiin yang telah di-install pada smartphone android. Ketika mata bergerak ke kanan maka aplikasi surah Yaasiin akan membuka halaman selanjutnya dan apabila mata bergerak ke kiri maka aplikasi surah Yaasin akan membuka halaman sebelumnya. Pergerakan mata ke kanan dan ke kiri dilakukan sebanyak 20 kali untuk memperoleh nilai akurasi dan nilai error. Akurasi merupakan ketepatan sistem dalam menampilkan respon sesuai dengan instruksi, sedangkan error merupakan kesalahan dimana respon tidak sesuai dengan instruksi. Nilai akurasi dan error dari setiap subjek dapat dilihat pada Tabel 2.

Tabel 2. Akurasi dan error sistem kontrol

\begin{tabular}{|l|l|l|l|l|}
\hline \multirow{2}{*}{ Subjek } & \multicolumn{2}{|l|}{ Kanan } & Kiri \\
\cline { 2 - 5 } & Akurasi & Error & Akurasi & Error \\
\hline 1 & $100 \%$ & $0 \%$ & $75 \%$ & $25 \%$ \\
\hline 2 & $80 \%$ & $20 \%$ & $90 \%$ & $10 \%$ \\
\hline 3 & $75 \%$ & $25 \%$ & $90 \%$ & $10 \%$ \\
\hline 4 & $75 \%$ & $25 \%$ & $95 \%$ & $5 \%$ \\
\hline 5 & $90 \%$ & $10 \%$ & $80 \%$ & $20 \%$ \\
\hline Rata-rata & $84 \%$ & $16 \%$ & $86 \%$ & $14 \%$ \\
\hline
\end{tabular}

Dari hasil pengujian yang diperoleh nilai ratarata akurasi untuk pergerakan mata ke kanan sebesar $84 \%$ dan ke kiri sebesar $86 \%$, sedangkan nilai rata-rata error untuk pergerakan mata ke kanan sebesar $16 \%$ dan ke kiri sebesar $14 \%$. Error dapat terjadi karena waktu pergerakan mata dapat berbeda-beda sehingga tegangan yang dihasilkan tidak sesuai dengan nilai batas yang ditetapkan. Waktu pergerakan mata yang ditahan terlalu lama dapat mengakibatkan respon seperti bergerak kearah sebaliknya atau dalam aplikasi ditandai dengan aplikasi membuka halaman selanjutnya tetapi ketika lurus akan kembali ke halaman sebelumnya sehingga halaman yang ditampilkan tetap seperti halaman sebelum melakukan gerakan mata atau justru menampilkan halaman sebelumnya. Apabila 
waktu pergerakan yang terlalu singkat maka tegangan yang dihasilkan tidak sampai pada batas pergerakan mata sehingga pada aplikasi tidak menunjukkan respon apa-apa.

\section{KESIMPULAN DAN SARAN Kesimpulan}

Sistem kontrol berbasis biopotensial mata untuk mengontrol aplikasi surah Yaasiin berbasis Android telah berhasil dirancang dan dibangun. Komponen yang digunakan adalah elektroda $\mathrm{Ag} / \mathrm{AgCl}$, pengkondisi sinyal berupa penguat instrumentasi, Driven Right Leg (DRL), High Pass Filter, Low Pass Filter, penguat noninverting dan penguat penjumlah yang selanjutnya diproses menggunakan Arduino Uno dan dikirim ke smartphone Android dengan koneksi Bluetooth. Dari pengujian sistem diperoleh akurasi rata-rata ke kanan sebesar $84 \%$, ke kiri sebesar $86 \%$ dan error rata-rata ke kanan sebesar $16 \%$, ke kiri sebesar $14 \%$.

\section{Saran}

Saran untuk penelitian selanjutnya adalah :

1. Memperhatikan kondisi kesehatan mata subjek penelitian.

2. Memvariasikan subjek untuk berbagai usia dengan rentang usia yang berjauhan.

3. Memperhatikan sudut pergerakan mata.

4. Menambah channel untuk pergerakan mata ke atas dan ke bawah.

5. Menggunakan program dengan logika seperti rangkaian flip-flop untuk meningkatkan nilai akurasi.

\section{DAFTAR PUSTAKA}

Bentley, J. P. (2005). Principles Of Measurement Systems. England: Pearson Education.

Cleveland Medical Device Inc. (2006). Biopotential Basics Student. Retrieved Desember 7, 2016, from Great Lakes Neurotechnologies: https://glneurotech.com/docrepo/teachinglabs/BioPotential_Basics_Student.pdf

Constable, P. A., Bach, M., Frishman, L. J., Jefferey, B. G., \& Robson, A. G. (2017,
Januari 1). ISCEV Standard for clinical electro-oculoghraphy (2017 update). ISCEV STANDARDS, 1-9. doi:10.1007/s10633017-9573-2

Fleury, A., Sugar, m., \& Chau, T. (2015, Februari 25). E-textiles in Clinical Rehabilitation: A Scoping Review. (W. Scanlon, A. Alomainy, \& N. Timmons, Eds.) Electronics, 4, 173-203.

Gunawan, H. (2011). Alat Untuk Memperagakan Irama Denyut Jantung Sebagai Bunyi dan Pengukur Kecepatan Denyut Jantung Melalui Elektroda pada Telapak Tangan. Electrical Engineering Journal, 2, 45-65.

Hadiyoso, S., \& Rizal, A. (2015). Instrumentasi Biomedis Berbasis PC. Yogyakarta: Gava Media.

Hidayat, W. S. (2012). Kinerja Butterworth LowPass Filter pada Teknik Modulasi Digital ASK Terhadap Paket Data yang dipengaruhi oleh Derau. InComTech, 3(2), 169-183.

Namdev, K., \& Siddiqui, M. M. (2015, Februari). Different Types Of Electrical Signals Produced By Human Body. International Journal of Advance Research In Science And Engineering, 4(2), 232-239.

Storey, N. (2009). Electronics : A Systems Approach (4th ed.). England: Pearson Education Limited.

Suryanto. (2007, Nopember 20). Kalibrasi Elektroda Referensi. Prosiding Pertemuan Ilmiah Nasional Rekayasa Perangkat Nuklir, 35-44.

Webster, J. G. (2009). Medical Instrumentation : Aplication And Design (4th ed.). USA: John Wiley \& Sons, Inc. 